\title{
Characteristics of sulfur hexafluoride hydrate film growth at the vapor/liquid interface
}

\author{
Soo Min Kim, Hyun Ju Lee, Bo ram Lee*, Yoon Seok Lee, Eun Kyung Lee, Ju Dong Lee** and \\ Yang Do $\mathrm{Kim}^{\dagger}$ \\ School of Materials Science and Engineering, Pusan National University, Busan 609-735, Korea \\ *Department of Chemical Engineering, Pohang University of Science and Technology (POSTECH), Pohang 790-784, Korea \\ **Dongnam Technology Service Division, Korea Institute of Industrial Technology, Busan 618-230, Korea
}

(Received March 3, 2010)

(Revised March 15, 2010)

(Accepted April 2, 2010)

\begin{abstract}
SF}_{6}$ gas has been widely used in many industrial fields as insulating, cleaning and covering gases due to its outstanding arc-extinguishing and insulating properties. However, global warming potential of $\mathrm{SF}_{6}$ gas is 23,900 times more than that of $\mathrm{CO}_{2}$ and it remains in the air during 3,200 years. For these reason, technological and economical effects could be expected for the separation of $\mathrm{SF}_{6}$ from gas mixtures by hydrate forming process. In this study, we carried out morphological studies for the $\mathrm{SF}_{6}$ hydrate crystal to understand its formation and growth mechanisms. $\mathrm{SF}_{6}$ hydrate film was initially formed at the interfacial boundary between gas and liquid regions, and then subsequent dendrite crystals growth was observed. The dendrite crystals grew to the direction of gas region probably due to the guest gas concentration gradient. The detailed growth characteristics of $\mathrm{SF}_{6}$ hydrate crystals such as nucleation, migration, growth and interference were discussed in this study.
\end{abstract}

Key words Hydrate, Sulfur hexafluoride, Film growth, Dendrite

\section{기상/액상 계면에서의 $\mathrm{SF}_{6}$ 하이드레이트 필름 성장거동 연구}

김수민, 이현주, 이보람*, 이윤석, 이은경, 이주동**, 김양도

부산대학교 재료공학부, 부산, 609-735

**포항공과대학교 화학공학과, 포항, 790-784

**한국생산기술 연구원 동남권기술지원본부, 부산, 618-230

(2010년 3월 3일 접수)

(2010년 3월 15일 심사완료)

(2010년 4월 2일 게재확정)

요 약 $\mathrm{SF}_{6}$ 가스는 아크방지능력과 절연 특성이 탁월하기 때문에 단열, 세척, 차폐등과 같은 여러 공업적인 영역에서 널리 사용되고 있다. 그러나 $\mathrm{SF}_{6}$ 의 지구온난화지수는 $\mathrm{CO}_{2}$ 의 23,900 배에 달하며 3,200 년 이상 공기중에 잔존한다. 이러한 이유로 하이드레이트 형성 원리를 이용하여 복합 가스에서 $\mathrm{SF}_{6}$ 를 분리해 내는 방법이 기술적, 경제적인 면에 영향을 끼칠 것이다. 본 연구에서 $\mathrm{SF}_{6}$ 하이드레이트 결정의 형성과 성장에 대한 이해를 위하여 형태학적 분석을 수행하였다. $\mathrm{SF}_{6}$ 하이 드레이트 필름은 용액과 기상의 계면에서 먼저 생성되었고, 이후에 수지상 가지의 형태로 성장하는 것이 관찰 되었다. 수 지상 성장 결정은 기상의 방향으로 성장하였는데 이것은 객체 분자의 농도 차이에 근거한 것으로 사료된다. 본 연구에서는 기/액 계면에서의 핵생성, 유동, 성장과 같은 $\mathrm{SF}_{6}$ 하이드레이트 결정의 형태학적 특성에 대하여 기술하였다.

\section{1. 서 론}

$\mathrm{SF}_{6}($ sulfur hexafluoride)는 불화가스의 일종으로써 단

\footnotetext{
Corresponding author

Tel: $+82-51-510-3439$

Fax: +82-51-514-4457

E-mail: yangdo@pusan.ac.kr
}

열, 아크방지능력(arc-extinguishing property), 안정성 등이 뛰어나서 전력용 변압기의 절연용 가스, 반도체 · 액정용 플라즈마 CVD의 Cleaning 가스, 주물공장의 Covering 가스 등으로 많이 사용되고 있다. 특히, 최근 중국과 중 동 등의 전력수요가 급속히 확대됨에 따라 변압기용 절 연가스의 수요도 증대되고 있으며, 국내에서도 반도체 액정 TFT 생산라인용으로 사용하기 위하여 대량 생산되 
고 있다. 하지만 $\mathrm{SF}_{6}$ 는 $\mathrm{CO}_{2}$ 대비 23,900 배의 지구온난 화지수(global warming potential)를 갖고 있기에 기후변 화에 미치는 영향이 $\mathrm{CO}_{2}$ 보다 훨씬 크다. 또한 대기 중 에서 분해되지 않고 남아있는 기간이 $\mathrm{CH}_{4}$ 는 10 년, $\mathrm{CO}_{2}$ 및 $\mathrm{CFCs}$ 는 100 년으로 추정되는 반면, $\mathrm{SF}_{6}$ 는 3,200 년으 로 극히 오랜 기간 분해되지 않고 대기 중에 잔존하므로 연간 방출되는 양은 상대적으로 작지만 오랜 기간 누적 되면 지구 온난화에 치명적으로 작용한다. 또한 $\mathrm{SF}_{6}$ 의 분리·회수 및 정제기술의 보유는 향후 $\mathrm{CDM}$ (clean development mechanism)사업에 의한 $\mathrm{CO}_{2}$ 배출권 확보 와 온실가스 거래(emission trading)시장에서 유리한 위 치를 확보할 수 있는 기반기술이 된다. 따라서 절연특성 과 안정성이 탁월한 $\mathrm{SF}_{\sigma}$ 의 원활한 사용을 위해서는 적 절한 분리/회수 기술 마련이 시급하다.

가스 하이드레이트는 낮은 기온 $(283.15 \mathrm{~K}$ 이하)과 높 은 압력 $(0.1 \mathrm{MPa}$ 이상) 상태에서 저 분자량의 가스(guest gas)가 순수한 물(host water)과 물리적 결합(hydrogen bond)에 의해 얼음과 유사한 고체상태의 결정으로 존재 하는 화합물을 말한다. 가스 하이드레이트의 구조는 얼 음과 유사하지만 가스 분자(guest gas)가 포집될 수 있 는 공동(cavity)을 가지고 있는 점이 특징이다. 객체 가 스의 크기와 모양에 따라 크게 구조I, 구조II, 구조H 세 가지 형태의 구조를 가진다[1-3].

가스 하이드레이트는 압축 천연가스에 비해 체적당 가 스 질량이 크고 액화 천연가스에 비해 상대적으로 유리 한 온도 및 압력 저장 조건으로 인해 경제적인 천연가스 의 저장 및 수송 수단으로 주목을 받고 있다 $[4,5]$. 지구 온난화가스인 이산화탄소를 연소가스로부터 분리하는 기 술, 하이드레이트로 고체화하여 열역학적으로 안정한 해 저퇴적층 및 대염수층에 지정학적으로 저장하는 기술, 그리고 이산화탄소를 천연 메탄 하이드레이트층에 주입 하여 메탄 분자와 이산화 탄소 분자를 치환시키는 기술 들의 개발이 적극적으로 시도되면서 연구와 관심이 집중 되고 있다[6-9].

가스 하이드레이트는 대부분 고압, 저온에서 형성 가 능하지만 불화가스에 대해서는 그보다 낮은 조건에서도 쉽게 결정화가 된다. 특히 $\mathrm{SF}_{6}$ 는 $276.15 \mathrm{~K}, 0.1 \mathrm{MPa}$ 에 서 고밀도로 고상화가 가능하다[10]. 따라서 $\mathrm{SF}_{6}$ 가 여러 기체와 혼합되어 있는 경우, $\mathrm{SF}_{6}$ 만 포집하는 하이드레이 트를 형성시켜 고상화시킨 후 이를 해리시켜 순수한 $\mathrm{SF}_{6}$ 를 회수 및 분리 할 수 있다. 이 원리를 이용하여 기 타 다른 불화가스의 분리 - 회수에 적용할 경우에 기술적, 경제적으로 주목할만한 효과를 기대할 수 있다.

본 연구에서 수행된 형태학적 연구(morphological study)는 생성되거나 분해되는 하이드레이트와 이를 둘 러싼 주변의 상 사이 경계의 모양과 크기에 관심을 두고, 결정의 핵들이 어떻게 생성되고 이동하며 성장하고 서로
간섭하는 지를 연구하는 분야이다 $[11,12]$ 형태학은 가스 하이드레이트가 생성되고 있는 국부 온도, 객체 분자 농 도 및 이들의 구배와 성장 속도 같은 인자들과 거시적 특성의 관계를 규명함으로써, 하이드레이트를 응용한 이 산화탄소 처리기술과 에너지 생산, 저장 및 수송 기술 (GTS; gas to solid technology) 개발에 필수 불가결한 도움을 준다[13]. 본 연구에서는 $\mathrm{SF}_{6}$ 하이드레이트 결정 의 형성(nucleation)과 성장기구(growth mechanism)를 규명하기 위하여 형태학적 연구를 수행하였으며, $\mathrm{SF}_{6}$ 하 이드레이트의 핵 생성 및 성장과 성장 형태에 대하여 기 술하였다.

\section{2. 실험 장치 및 방법}

\section{1. 실험 장치}

Fig. 1은 본 연구에 사용된 실험장치의 사진이다. 본 실험에서 사용하는 하이드레이트 생성 용기는 폴리카보 네이트 수지로 이루어져 있어서 열전도율이 낮기 때문에 용기 내부의 용액이 안정화된 온도에서 쉽게 변하지 않 는다. 폴리카보네이트 수지로 구성된 중공 기둥용기의 상단 및 하단에 각각 스테인리스 스틸 소재의 뚜껑을 조 립한다. 반응기 내부의 기밀을 유지하기 위해서 스테인 리스 뚜껑을 볼트와 너트를 사용하여 조이고, 중공 기둥 용기와 뚜껑의 접촉부에 o-ring을 사용하였다. 관찰을 최 대한 용이하게 하기 위해서 조립에 사용된 볼트를 3개 로 제한하여 시야각이 넓도록 설계 하였다. 볼트가 관통 하는 위치에 따라 최대한의 관찰이 가능하도록 볼트 사

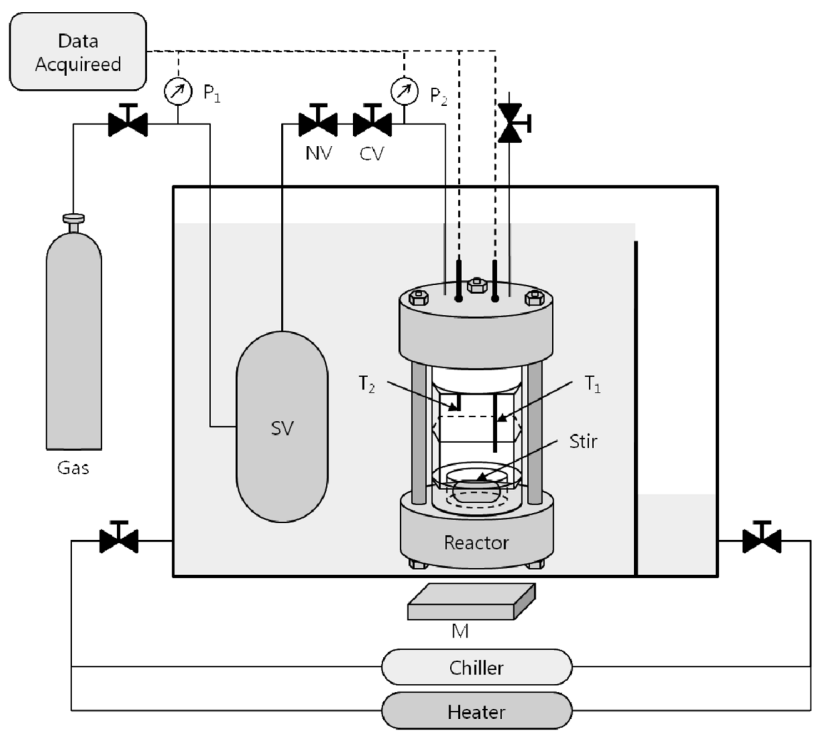

SV: Supply Vessel NV: Needle Valve CV: Control Valve M : Magnetic Stir

Fig. 1. Morphology experimental apparatus. 
이의 공간에 중공 컬럼의 표면을 평평하게 깍았다. 중공 칼럼의 내부 또한 표면에 수평하게 깍았기 때문에 표면 굴곡에 의한 반사나 측정 영상의 크기 오차가 없도록 하 였다. 그리고 반응기 내부에 삽입된 자석 젓개(magnetic bar)이 위치하는 하부의 구조를 원형으로 하여서 교반이 수월하게 되도록 설계하였다. 메모리 워터를 제조하기 위해서는 반응기 속의 용액에 대한 교반이 필수적인데, 용액의 효율적인 교반을 위해 용기의 내부에 삽입된 자 석 젓개(magnetic bar)를 수조의 밑에서 자석 교반기 (magnetic stirrer)로 구동시켰다.

조립된 용기는 온도가 제어되는 일수식 수조에 완전히 잠기게 한다. 이때 수조의 외벽은 $10 \mathrm{~mm}$ 두께의 투명한 아크릴로 만들어 외부로부터 육안 및 현미경을 통한 관 찰이 가능하도록 하였고, 금속 재질에 비해서 열전도율 이 떨어지기 때문에 수조 내부의 온도가 크게 변하지 않 는다. 수조에 사용되는 냉매는 영하의 온도에서도 얼지 않도록, 자동차의 부동액으로 흔히 사용되는 에틸렌 글 리콜을 물과 $2: 8$ 의 비율로 섞어서 사용하였다. 또한 수 조의 온도를 신속히 제어할 수 있도록 두 개의 항온조와 순환 펌프 및 밸브, 배관 시스템으로 연결하여 냉매를 직접 순환시켰다.

수조에 비추는 조명은 형태학(morphology)적 실험의 관찰에서 관찰영상의 질을 결정하는 매우 중요한 인자이 다. 본 실험에서는 Nikon 사가 제작한 용량 $300 \mathrm{~W}$ 의 할로겐 광원과 이에 부착된 두 개의 거위목 광섬유 관을 사용하여 조명을 수조의 외부에서 수조벽과 중공 기둥을 관통하도록 조사하였다. 또한 빛의 난반사가 발생하지 않도록 광원을 2 개 사용하였다. 형태학적 실험에 대한 관측은 광학 현미경(Nikon, SMZ1000)을 이용하였다. 관측 기록은 광학 현미경에 장착된 $\mathrm{CCD}$ 카메라(Sony, DXC-390)와 디지털 카메라(Canon, powershot A620)를 이용하여 기록하였다.

\section{2. 실험방법}

실험을 준비하는 과정은 다음과 같다. 먼저 용기를 구 성하는 부품의 습기와 먼지를 완전히 제거하고 반응기를 조립한 뒤, 약 $25 \mathrm{cc}$ 의 순수한 물을 반응기(용기) 내에 주입한다. 이어서 수조의 온도를 제어하여 반응기의 내 부 온도가 설정한 초기 온도에 이르도록 한 뒤, 반응기 내부의 공기를 제거하기 위해 객체 가스(guest gas)를 용기 내부에 $0.5 \mathrm{MPa}$ 이상의 압력으로 충진하고 0.1 $\mathrm{MPa}$ 부근까지 방출하는 Cleaning 과정을 3회 이상 반 복하였다.

기억효과(memory effect)를 부여하고 하이드레이트 생 성 시험까지 유동을 정지시키는 경과시간 동안 시간에

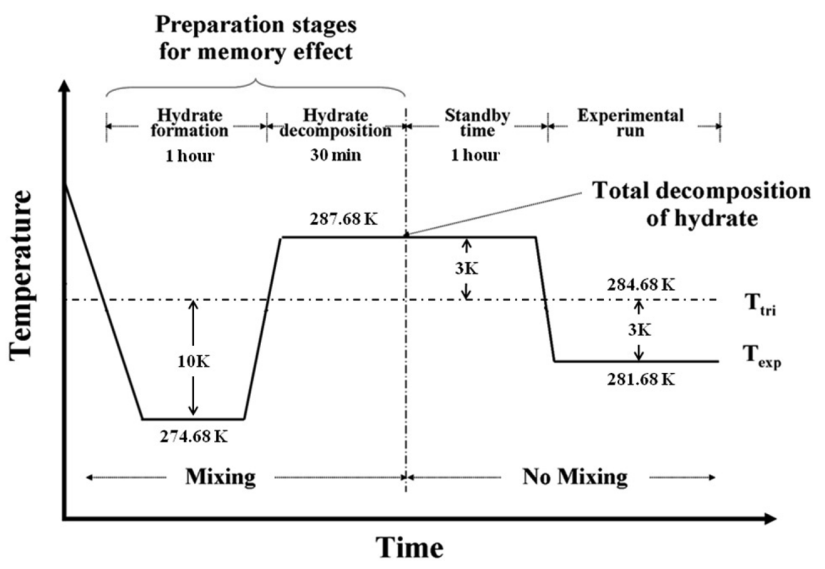

Fig. 2. Transient change of temperature during preparation stages and experimental run at $1 \mathrm{MPa}$.

따른 용액의 온도의 변화를 Fig. 2에 개략적으로 나타내 었다. 본 실험은 객체 가스의 압력을 $1.0 \mathrm{MPa}$ 로 고정하 여 수행되었다. Fig. 2에서, $\mathrm{T}_{\mathrm{tri}}$ 는 하이드레이트-혼합기체용액 $(\mathrm{H}-\mathrm{V}-\mathrm{L})$ 의 3 개 상이 해당 압력에서 평형으로 공존 하는 3 상 평형온도이다. 매질의 온도 $\left(\mathrm{T}_{\exp }\right)$ 가 3 상 평형온 도 $\left(\mathrm{T}_{\mathrm{tri}}\right)$ 보다 낮은 구간에서는 하이드레이트 생성조건이 평형온도 보다 높은 구간에서는 분해조건이 부여된다.

모든 실험에서 하이드레이트 결정의 성장특성을 관찰 하기 전에 기억효과(하이드레이트가 분해된 후에도 물 분자의 입체 그물 결합구조가 잔존하는 현상)를 부여하 는 과정을 먼저 수행하였다. 이 과정은 Fig. 2에 나타낸 바와 같이 약 1 시간 동안 매질의 온도를 평형온도보다 $10 \mathrm{~K}$ 낮게 유지하는 하이드레이트 생성 단계와 매질의 온도를 평형온도 $\left(\mathrm{T}_{\text {tri }}\right)$ 보다 $3 \mathrm{~K}$ 높은 온도로 유지하는 하 이드레이트 분해 단계로 구성된다. 기억효과를 부여하는 과정 중에는 지속적인 용액의 교반이 병행되며 하이드레 이트의 분해가 완료되는 시간은 수행된 실험조건에서 30 분 이하이다. 현미경을 통해 하이드레이트 결정이 완 전히 사라진 것을 확인하면, 교반을 멈추고 1 시간의 유 지시간(standby time)을 가진다. 기억효과를 갖는 수용액 을 사용하는 이유는 하이드레이트 생성조건이 만족된 시 점에서 결정의 생성이 관측되는 순간까지 걸리는 핵생성 시간(induction time)을 단축하기 위함이다. 기억효과를 갖지 않은 용액(fresh liquid solution)을 사용하는 경우 과냉 조건에 따라 수 일에서 1 주 정도까지의 유도시간 이 필요하지만 기억효과를 갖는 수용액을 사용한 경우 모든 실험에서 하이드레이트 생성조건이 만족되고 2시간 이내에 하이드레이트 결정이 관찰되었다. 유지시간(standby time)을 충분히 가진 후 반응기의 온도를 평형온도 $\left(\mathrm{T}_{\mathrm{tri}}\right)$ 보다 $3 \mathrm{~K}$ 낮은 온도로 유지하여 하리드레이트 결정 성 장 거동을 관찰하였다. 

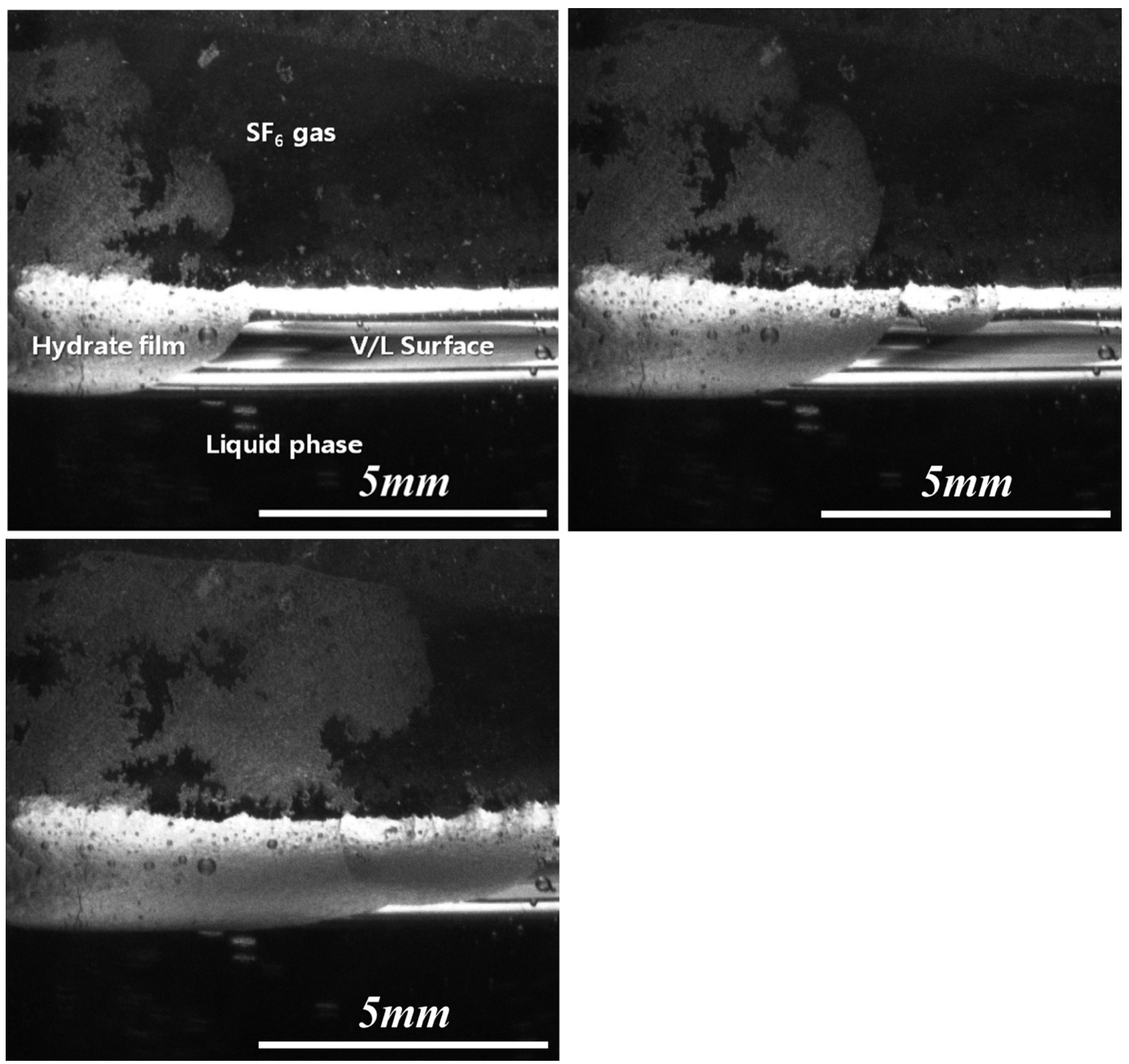

Fig. 3. $\mathrm{SF}_{6}$ hydrate film growth at gas/water interface.

\section{3. 결과 및 고찰}

\section{1. $\mathrm{SF}_{6}$ 하이드레이트 결정 성장 관찰}

Fig. 3에 하이드레이트 필름이 형성되는 과정을 나타 내었다. 관찰결과에서 확인할 수 있듯이 하이드레이트는 기/액 계면에서 처음으로 자라기 시작하는 것을 확인 할 수 있다. 하이드레이트 필름이 계면을 모두 덮는 시간은 약 30 초 가량 소요 되었다. $\mathrm{CO}_{2}$ 하이드레이트의 필름 성장 속도가 약 2 3초 정도인 것과 비교해 볼때 $\mathrm{SF}_{6}$ 하 이드레이트 필름의 성장속도가 매우 느림을 알 수 있다. 본 실험에서 관찰한 $\mathrm{SF}_{6}$ 하이드레이트 필름의 성장 속 도는 $0.83 \mathrm{~mm} / \mathrm{s}$ 의 속도로 일정하게 성장하는 것을 확 인 하였다. 기/액 계면 아래의 액상 영역에서는 하이드 레이트가 전혀 생성되지 않았다. 메탄/프로판 혼합 가스 를 이용한 하이드레이트의 생성시 액상 영역에서 수많은 부유 입자(floating particles)들이 형성되어서 기/액 표면 에 달라붙어서 성장하는 거동을 보이는데 $\mathrm{SF}_{6}$ 하이드레
이트의 경우에는 이러한 부유 입자가 전혀 관찰되지 않 았다[14].

$\mathrm{SF}_{6}$ 하이드레이트의 결정 성장 형태를 Fig. 4에 나타 내었다. Fig. 4에서 확인할 수 있는 것처럼 필름을 형성 한 이후에 필름의 기상 접촉 면에서부터 수지상 가지 (dendrite branch)가 기상 방향으로 자라는 모습을 확인할 수 있다. 이러한 거동은 $\mathrm{SF}_{6}$ 하이드레이트 수지상 가지의 수가 증가하고 길이가 길어짐에 따라서 기/액 접촉면의 가운데 부분이 함몰되는 결과를 나타낸다. 수지상의 성장 속도 또한 필름의 성장 속도와 거의 같으며, 주 성장 가 지와 2차 성장 가지를 가지는 형태로 관찰 되었다.

필름 표면에서의 수지상 성장에 대한 자세한 사진을 Fig. 5에 나타내었다. Fig. 5는 하이드레이트 필름 성장 이 완료된 후 필름과 기상의 접촉부에서 밤송이 모양의 하이드레이트가 성장하는 모습을 보여준다. 수지상 가지 는 주로 기상에 가까운 방향으로 길게 자라는 것으로 관 찰되었다. 형성된 $\mathrm{SF}_{6}$ 하이드레이트는 각각의 수지상 가 지(dendrite branch)가 $0.2 \mathrm{~mm} / \mathrm{s}$ 의 일정한 속도로 방사 

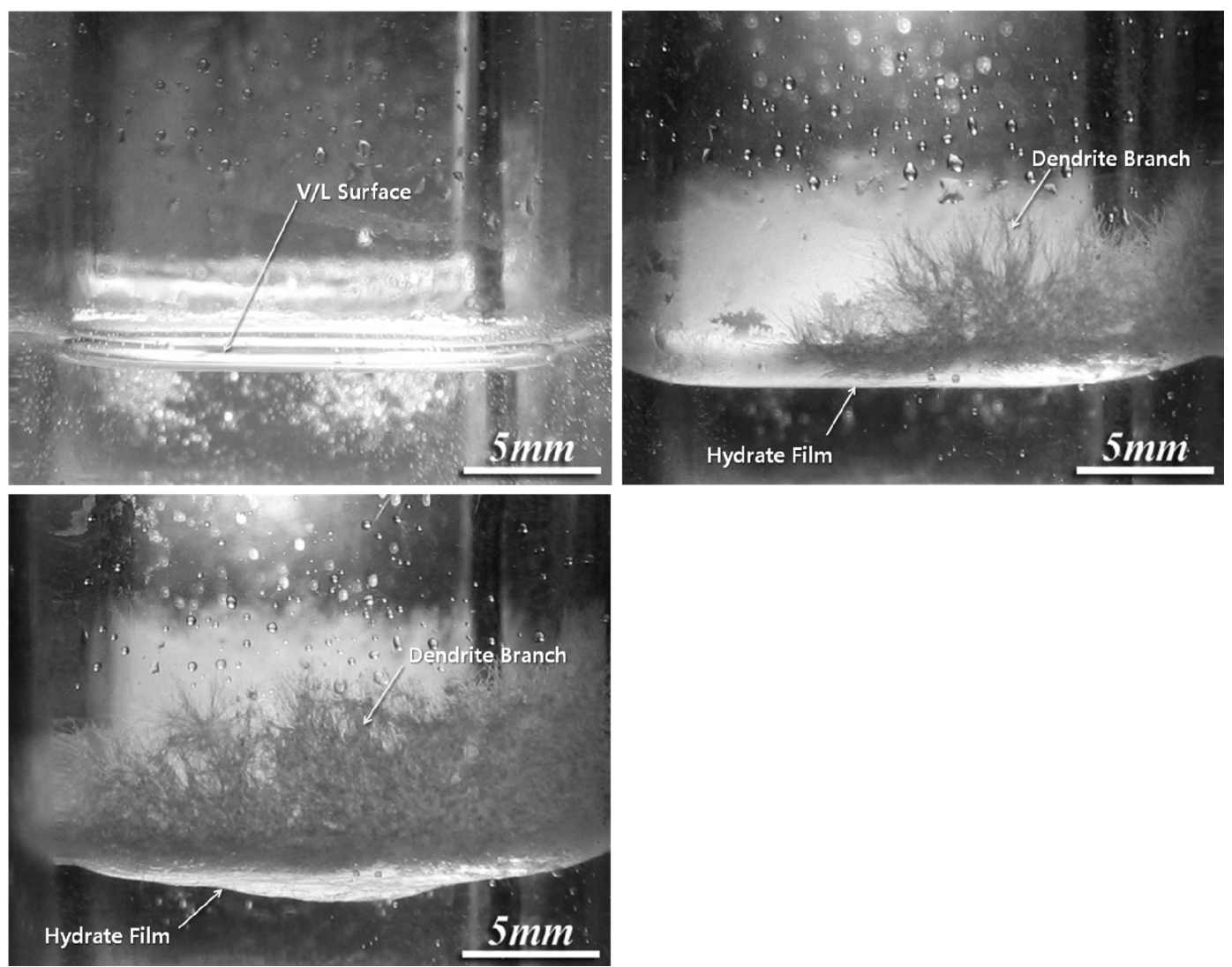

Fig. 4. $\mathrm{SF}_{6}$ hydrate dendrite growth at gas/water interface.
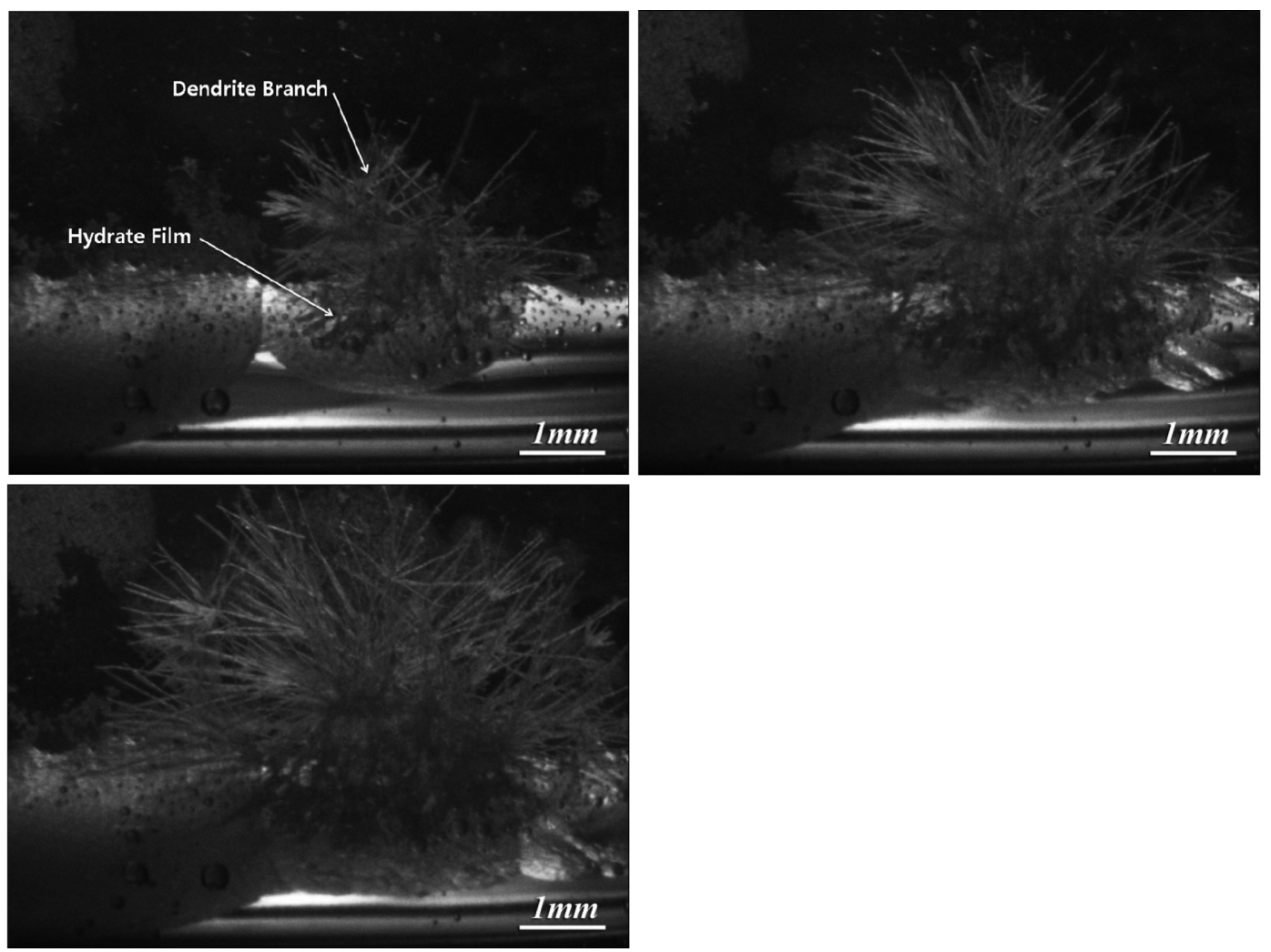

Fig. 5. Dendrite crystal growth on $\mathrm{SF}_{6}$ hydrate film. 


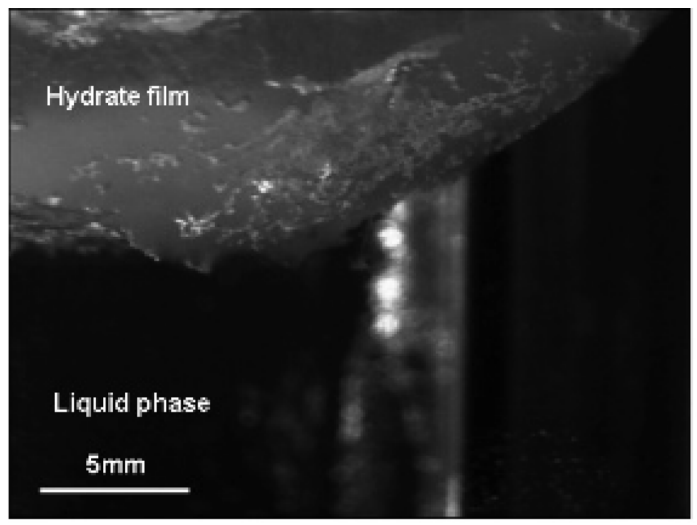

(a) $10 \mathrm{~min}$

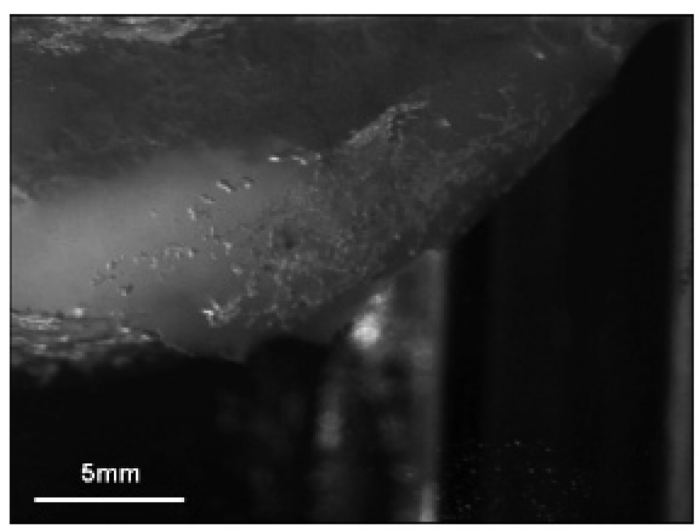

(c) $16 \mathrm{~min}$

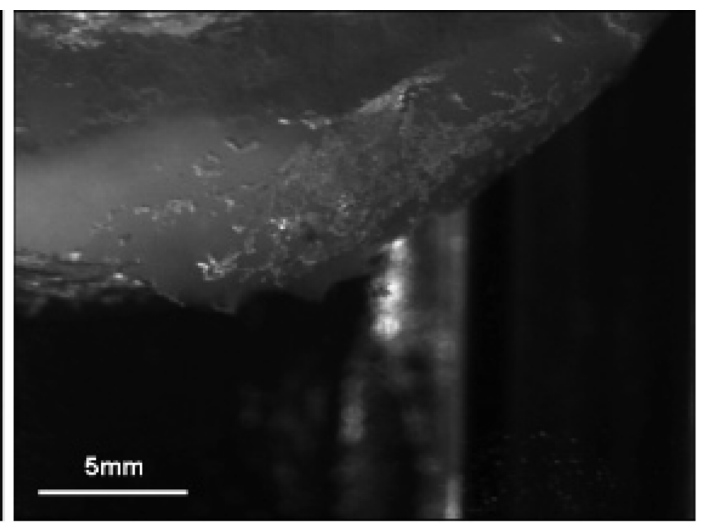

(b) $13 \mathrm{~min}$

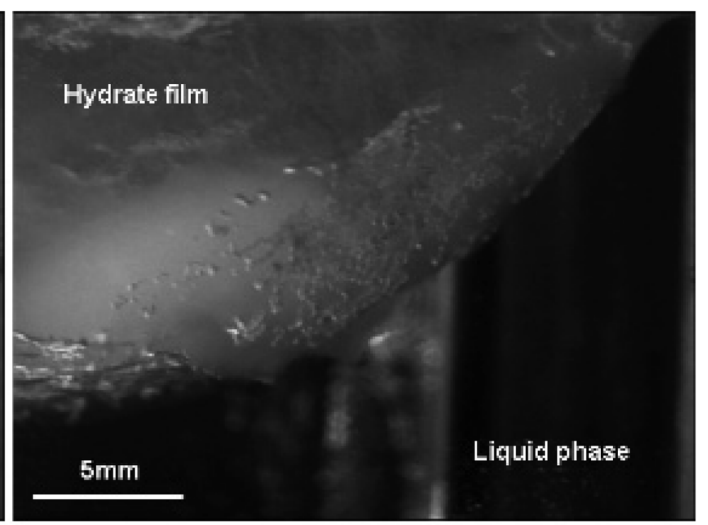

(d) $19 \min$

Fig. 6. $\mathrm{SF}_{6}$ hydrate film depression with dendrite branch growth.

형 성장을 하였다. 밤송이 모양의 하이드레이트가 생성 되고 성장되는 모든 과정 동안에 액상부에서는 하이드레 이트의 생성이나 성장이 전혀 관찰되지 않았다.

이러한 결과들은 Lee et al.[14]의 보고와는 정반대의 결과를 나타내고 있다. 메탄/프로판 하이드레이트의 경우 에 부유 입자(floating particles)는 액상의 하단부에서 생 성되어 기/액 경계면의 하이드레이트 필름 근처에 도달 한 뒤 수지상으로 성장하며 주 가지와 직각방향으로 2 차 가지가 계속해서 성장하는 형상을 이룬다. 이와는 대 조적으로 본 실험에서는 Fig. 4나 Fig. 5와 같이 $\mathrm{SF}_{6}$ 하 이드레이트는 액상 내부로의 어떤 성장도 없었으며, Fig. 6 에 나타난 것과 같이 $\mathrm{SF}_{6}$ 하이드레이트 수지상 가지가 상부에서 성장할 수록 하이드레이트 필름의 위치가 아래 방향으로 낮아지는 현상을 보였다.

\section{2. 결정의 성장 이론}

본 실험에서 관찰한 결과 하이드레이트의 초기 생성은 항상 기/액 표면에서 발생하였다. Fig. 7에 기/액 경계로 부터 거리에 따른 물과 객체분자의 농도 기울기를 나타 내었다. 일반적으로 평형상태의 기/액 경계 부근 객체
분자 농도는 액상 내부와 크게 차이가 없다. 하지만 $\mathrm{SF}_{6}$ 가스는 물에 대한 용해도가 $293.15 \mathrm{~K}, 0.1 \mathrm{MPa}$ 에서 $0.0003 \mathrm{~mol} / /$ 로 매우 작기 때문에 Fig. 7(b)에 표현된 것 과 같은 객체 분자 농도 곡선을 가진다. 따라서 전체 용 액을 기준으로 하였을 경우 기/액 경계 부근에 대부분의 객체 가스가 높은 농도로 존재하게 된다. 하이드레이트 가 형성되기 위해서는 물과 함께 일정한 양의 객체 분자 가 반드시 요구된다. $\mathrm{SF}_{6}$ 의 경우 결정 구조 $\mathrm{II}$ 를 형성하 며 $\mathrm{SF}_{6}$ 분자가 포집되는 공동(cavity: $5^{12} 6^{4}$ )과 물 분자의 화학양론적 비율이 $8: 136$ 이기 때문에 하이드레이트 형 성을 위해서는 객체 분자와 물 분자의 몰비율이 적어도 $1: 17$ 이상으로 유지 되어야 한다[15]. Fig. 7(b)에 나타 낸 것과 같이 기/액 경계에서 멀어질수록 객체 분자의 농도가 감소하고 하이드레이트 형성에 필요한 조성비를 맞추기가 어렵게 된다. 이러한 이유로 $\mathrm{SF}_{6}$ 하이드레이트 는 객체 분자의 농도가 상대적으로 높은 기/액 경계면에 서 초기 생성 및 성장이 일어나는 것으로 사료된다.

$\mathrm{SF}_{6}$ 하이드레이트 필름이 형성된 이후에 수지상 가지 (dendrite branch)가 액상의 방향이 아닌 기상의 방향으 로 자라는 것을 Fig. 4와 Fig. 5에서 확인할 수 있다. 이 러한 사실은 기/액 표면에서의 하이드레이트 우선 성장 


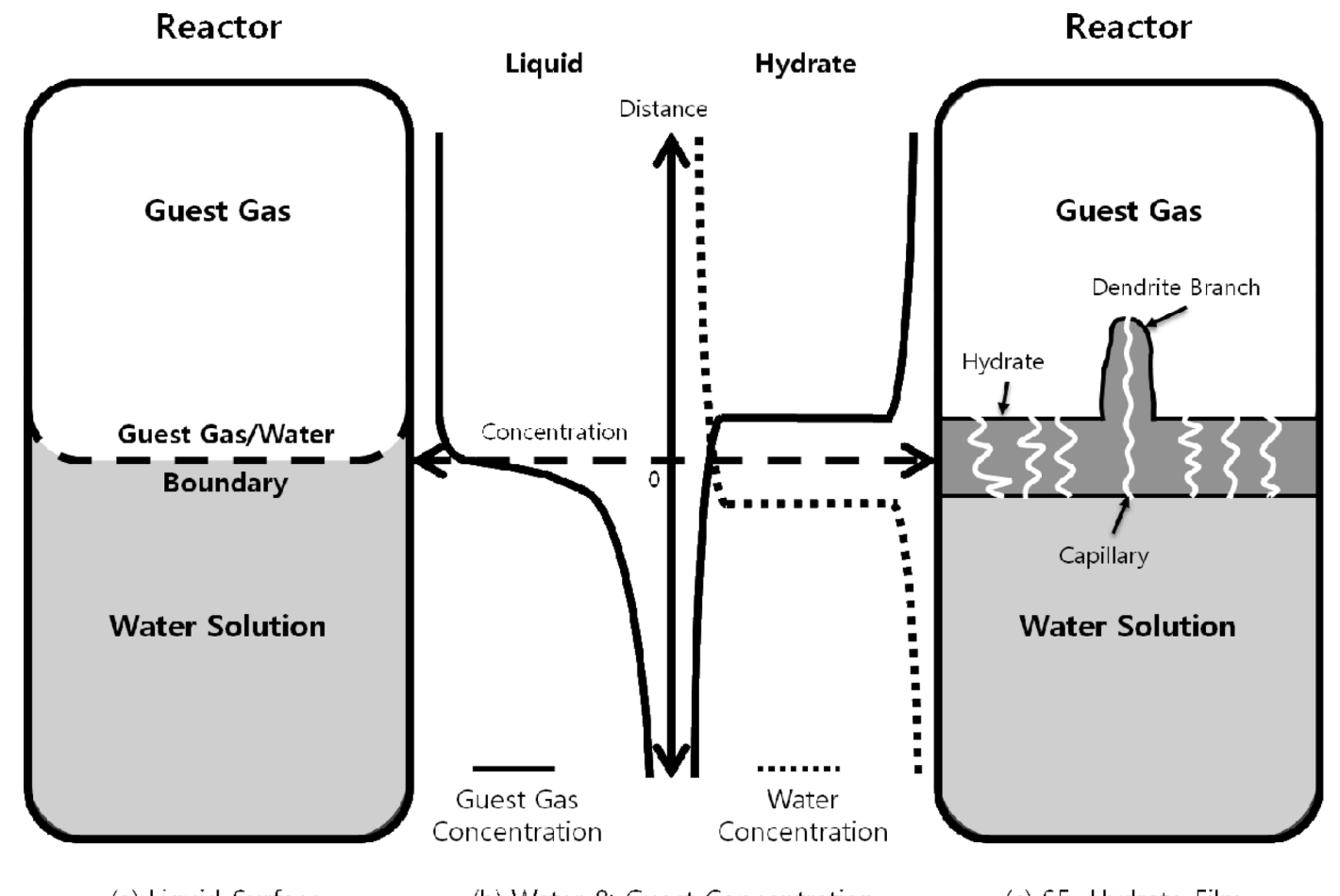

(a) Liquid Surface

(b) Water \& Guest Concentration

(c) $S F_{6}$ Hydrate Film

Fig. 7. Guest gas molecule concentration gradient and capillary model in hydrate film.

과 같이 객체 분자의 농도가 풍부한 기상의 방향으로 하 이드레이트가 성장하는 것으로 설명할 수 있다. 이를 설 명하기 위하여 Fig. 7(c)에 간단한 하이드레이트 형성 모델을 도시하였다. 하이드레이트 필름이 생성된 이후 기/액 경계면을 기준으로 객체 분자의 이동이 어렵게 된 다. 이로 인하여 Fig. 7(b)에 도시한 것과 같이, 반응기 내부에서 기상의 객체 가스 분자의 농도와 용액 내부의 객체 가스 분자 농도의 차이가 발생한다. 이러한 객체 가스 분자의 농도 구배는 하이드레이트 가지의 성장 방 향을 결정짓게 된다.

$\mathrm{SF}_{6}$ 하이드레이트 수지상 가지는 객체 분자의 농도가 높은 기상 방향으로 성장하게 된다. 이러한 성장을 설명 하기 위해서 반드시 필요한 내용이 용액의 물질 이동 경 로 규명이다. 실제로 형성된 하이드레이트 가지를 설명 하기 위해서 하이드레이트 모세관 이론을 사용하였다 $[16,17]$. 보고된 연구결과에 따르면 하이드레이트 필름 내부의 용액이 하이드레이트 필름의 표면으로 이동하는 물질이동 모델이 제시되었다. 이 모델에서는 몇 가지 전 제조건을 설정하였는데 중요한 내용은 다음과 같다. 우 선 하이드레이트 필름은 불투성 고체막으로 생각하여 어 떤 물질의 통과도 발생하지 않는다고 가정하였다. 또한 필름의 내부에 불규칙하게 분산된 모세관이 존재하여 모 세관을 통하여 필름 내/외부의 물질 이동이 발생한다고 가정하였고, 물과 필름 사이의 접촉면에서는 하이드레이 트의 해리가 발생하고 객체 가스와 하이드레이트 필름의
접촉면에서는 하이드레이트의 생성이 일어나는 것으로 가정하였다. 물질 이동의 방향은 주체(host water)에서 객체(guest liquid) 쪽으로 발생하는 것으로 보고 하였다. 본 실험에서도 마찬가지로 액상에서 기상 방향으로의 물 질 이동이 발생한 것으로 관찰되었다. 실험의 결과를 반 영하여 모세관 모델을 적용한 결과를 Fig. 7(c)에 도시 하였다. 본 실험의 관찰결과 발생한 물질 이동 경로는 하이드레이트 필름을 통과하는 주체(host water)에서 객 체(guest gas)로의 이동으로 판단된다. 결론적으로 $\mathrm{SF}_{6}$ 하이드레이트의 수지상 가지가 기상방향으로 자라는 가 장 큰 이유는 객체 분자의 농도 때문이며 하이드레이트 의 모세관 현상으로 인해서 기상방향으로 성장이 가능하 게 된 것으로 사료된다. 또한 주체(host water)의 물질이 동 구동력이 모세관력에 의한 물의 모세관 유동에 의존 하므로 하이드레이트 가지의 빠른 성장이 이루어 지지 않는 것으로 사료된다.

\section{4. 결 론}

지구 온난화 지수가 높은 $\mathrm{SF}_{6}$ 의 효과적인 처리를 위한 기초연구로써 $\mathrm{SF}_{6}$ 하이드레이트 결정의 성장을 관찰하였 다. 먼저 $\mathrm{SF}_{6}$ 하이드레이트는 기/액 경계면에서 필름 (film)형태로 형성되었으며, 하이드레이트 필름의 상부방 향으로 수지상 성장(dendrite growth) 거동을 나타내었다. 
형성된 하이드레이트 수지상 가지는 눈꽃 또는 밤송이와 유사한 형태로 자라났으며, 각각의 수지상 가지(dendrite branch)는 일정한 속도로 지속적으로 성장하였다. 다른 객체 가스의 하이드레이트 생성시 관찰되는 액상 내부의 부유 입자(floating particle)는 관측되지 않았다. 본 연구 에서는 이러한 $\mathrm{SF}_{6}$ 하이드레이트의 성장을 모세관 유동 을 이용한 물질이동을 통하여 설명하였고 성장의 구동력 은 하이드레이트 필름 내부에 존재하는 모세관의 모세관 력과 하이드레이트 필름 상/하부의 객체 분자 농도차로 사료된다. 상대적으로 다른 하이드레이트에 비하여 $\mathrm{SF}_{6}$ 하이드레이트가 느린 성장 속도를 보이는 이유는 모세관 력에 의존한 주체(host water)의 물질 이동 속도 때문인 것으로 판단된다. 본 실험에서 제시한 형태학(morphological study)자료와 성장거동 분석결과는 향후 $\mathrm{SF}_{6}$ 하이 드레이트 연구 및 생산의 기초 자료를 제공할 것으로 사 료된다.

\section{감사의 글}

본 연구는 지식경제부 에너지자원기술기획평가원 신재 생에너지기술개발 사업(2008NHY08P0200002009)의 지 원으로 수행되었기에 이에 감사드립니다.

\section{참 고 문 헌}

[1] E.D. Sloan, Clathrate Hydrates of Natural Gases 2nd ed., Marcel Dekker, New York (1998).

[ 2 ] H. Ganji, M. Manteghian, K. Sadaghiani Zadeh, M.R. Omidkhah and H. Rahii Mofrad, "Effect of different surfactants on methane hydrate formation rate, stability and storage capacity", Fuel. 86 (2007) 411.

[3] M.A. Clarke and P.R. Bisnoi, "Measuring and modeling the rate of decomposition of gas hydrates formed mixtures of methane and ethane", Chem Eng Sci. 56 (2001) 4715 .

[4] P. Englezos and J.D. Lee, "Gas hydrate: A cleaner source of energy and opportunity for innovative technologies", Korean J. Chem. Eng. 22(5) (2005) 671.

[ 5 ] H. Lee, J. Lee, D.Y. Kim, J. Park, Y.-T. Seo, H, Zeng, I.L. Moudrakovski, C.I. Ratcliffe and J.A. Ripmeester,
"Tuning clathrate hydrates for hydrogen storage", Nature 434(7034) (2005) 743.

[6] J.W. Lee, M.-K. Chun, K.M. Lee, Y.J. Kim and H. Lee, "Phase equilibria and kinetic behaviour of $\mathrm{CO}_{2}$ hydrate in electrolyte and porous media solutions: application to ocean sequestration of $\mathrm{CO}_{2}$ ", Korean J. Chem. Eng. 19(4) (2002) 673.

[7] O.R. West, C. Tsouris, S. Lee, S.D. McCallum and L. Liang, "Negatively buoyant $\mathrm{CO}_{2}$-hydrate composite for ocean carbon sequestration", AIChE J. 49(1) (2003) 283.

[ 8 ] Y.-T. Seo and H. Lee, "Structure and guest distribution of the mixed carbon dioxide and nitrogen hydrates as revealed by X-ray diffraction and $\mathrm{C}^{13}$ NMR spectroscopy", J. Phys. Chem. B 108(2) (2004) 530.

[9] Y.-T. Seo, I.L. Moudrakovski, J.A. Ripmeester, J.-W. Lee and $\mathrm{H}$. Lee, "Efficient recovery of $\mathrm{CO}_{2}$ from flue gas by clathrate hydrate formation in porous silica gels", Environmental Science and Technology 39(7) (2005) 2315.

[10] K. Sugahara, M. Yoshida, T. Sugahara and K. Ohgake, "Thermodynamic and raman spectroscopic studies on pressure-induced structural transition of $\mathrm{SF}_{6}$ hydrate", J. Chem. Eng. 51 (2006) 301.

[11] Y.F. Makogon, "Hydrates of natural gas", Penn Well, Tulsa, Oklahoma (1981) Chapter 2.

[12] M. Sugaya and Y.H. Mori, "Behaviour of clathrate hydrate formation at the boundary of liquid water and a fluorocarbon in liquid or vapor state", Chemical Engineering Science 51(13) (1996) 3505.

[13] S. Thomas and R.A. Dawe, "Review of ways to transport natural gas energy from countries which do not need the gas for domestic use", Energy 28(14) (2003) 1461.

[14] J.D. Lee, M. Song, R. Susilo and P. Englezos, "Dynamics of methane-propane clathrate hydrate crystal growth from liquid water with or without the presence of n-heptane", Crystal growth \& Design 6(6) (2006) 1428.

[15] G.A. Jeffrey, "Inclusion compounds", Atwood, J.L. Davies, J.E.D. and MacNichol, D.D., eds., Academic Press (1984) 135.

[16] Yasuhiko H. Mori and Takaaki Mochizuki, "Mass transport across clathrate hydrate films-a capillary permeation model", Chemical Engineering Science 52(20) (1997) 3613.

[17] I. Aya, K. Yamane and N. Yamada, "Stability of clathrate-hydrate of carbon dioxide in highly pressurized water", HTD-Vol. 215, Am. Soc. Mech. Engrs, New York, N.Y. (1992) 17. 